\title{
Marcin FELTYNOWSKI*
}

\section{THE VILLAGE FUND AS A SUPPORT TOOL IN SPATIAL PLANNING ACTIVITIES: A CASE STUDY OF POLAND}

\begin{abstract}
With respect to space, local authorities may deploy diverse instruments designed to promote the engagement of local communities in the spatial planning and decision-making process. The Village (Polish: Solecki) Fund, established for rural and urban-rural communes, is one of the ways for achieving this goal. Resources from the Village Fund may be used for, e.g. spatial planning, which is one of a commune's own tasks.

The activities related to the Village Fund have triggered studies focused on the units which run such funds and, on the amounts, earmarked for goals pertaining to spatial planning. On top of that, the spatial distribution of communes delivering such tasks has also been assessed. The analyses covered statistics as well as budget queries in communes which allocated funds for activities connected with spatial planning.
\end{abstract}

Key words: Village Fund, spatial planning, rural and urban-rural communes, Poland.

\section{INTRODUCTION}

A characteristic feature of local development is the existence of a specific system, referred to as a local system. Communes foster local development by involving local populations in management processes. A community's awareness of the issues and needs, combined with appropriate organisational structures (local institutions), prove the independence and distinctiveness of the created local systems (Jałowiecki, 1986; Misztal, 1986). This awareness is connected with grass-roots initiatives.

One of the elements of self-governance is the Village Fund, available in Poland since 2009. According to Starosta (1995), local development should be approached as a locally initiated, spontaneous, yet planned set of actions aimed at

\footnotetext{
* Marcin FELTYNOWSKI, University of Lodz, Faculty of Economics and Sociology, ul. POW 3/5, 90-255 Łódź, Poland; email: marcin.feltynowski@uni.lodz.pl
} 
transforming the economic, social, cultural, and environmental settings of a community. In the case of the discussed instrument, it becomes evident that in communes it should be considered the basis of self-governance, and the creation of local development belongs to residents of a village.

The main objective of the paper is to identify and assess the spatial distribution of communes within whose boundaries there exist villages which finance tasks related to spatial planning. Another objective is to identify the scale and scope of the disbursement of money from the Village Fund for spatial planning, combined with a basic statistical analysis of the phenomenon. In addition, in the theoretical part of the work, I indicate how spatial planning is an important task for communes, and I present the mechanism of how the Village Fund operates.

\section{SPATIAL PLANNING AS A COMMUNE'S TASKS}

Spatial planning is one of the basic tasks of a commune. Its role is to develop land in individual areas in a planned manner using the tools available to local authorities. Actions undertaken within the remit of a commune's tasks are expected to ensure spatial order in the commune.

In Poland, tools available for spatial planning in communes relate to the study of the conditions and directions of spatial development, which is a mandatory document. Land-use plans, which in principle are optional, are the most powerful tool that influences space organisation in communes. Alternatives to such documents can be sought in planning permits - decisions which specify the conditions for building up and developing an area when a land-use plan is missing (Nowak, 2012; Brzeziński, 2015; Brzeziński, 2016; Feltynowski, 2018a).

Activities linked to spatial planning should be considered from a broad perspective, i.e. from the preparatory actions up to the final product - the documents. From the perspective of the Village Fund, in all cases, they target spatial planning documents drafted upon the initiative of local authorities. Thus, resources from the Village Fund are not spent on planning permits issued at the demand of investors.

By approaching spatial planning as an opportunity to engage the local community in a dialogue about the allocation of resources from the Village Fund, I want to improve the quality of the dialogue and the overall culture of the processes surrounding spatial planning (Kolipiński, 2015; Feltynowski, 2018b). Engaging local communities in such efforts is also aimed at building relations with local authorities while alleviating conflicts that might arise when documents connected to spatial planning are drafted or amended. Such an approach should enhance the involvement of the local community in the drafting of a study and land-use 
plans (Chrisidu-Budnik and Korczak, 2018). By allocating Village Fund resources to tasks relating to spatial planning, I may reach out to a local community and inform them about what the local authorities intend to do in the field of spatial planning and how these decisions will be reflected in spatial development. Thus, the execution of tasks connected with spatial planning using resources from the Village Fund, besides the purely economic aspect, helps in accomplishing social objectives involved in the process.

\section{THE VILLAGE FUND IN RURAL AND URBAN-RURAL COMMUNES}

The Village Fund was established in rural and urban-rural ${ }^{1}$ communes as an instrument to help engage local communities in rural areas in decision-making processes. This local development tool was introduced in 2009 by the Village Fund Act, which became effective in April of the same year. The Act was amended with the Village Fund Act of 21 February 2014, which entered into force on 20 March 2014. Both acts were driven by the intention to involve communities in decision-making processes and improve residents' standards of living through investment projects. As a rule, the Village Fund is disbursed for activities within a catalogue of a commune's tasks. A commune's tasks, as enumerated in the Commune Self-government Act, include spatial order, which directly relates to the delivery of tasks in the field of spatial planning. In accordance with the wording of the Spatial Planning and Land Development Act of 2003, spatial order means a harmoniously shaped space that in orderly relationships considers all circumstances and meets functional, social, economic, environmental, cultural, compositional, and aesthetic requirements.

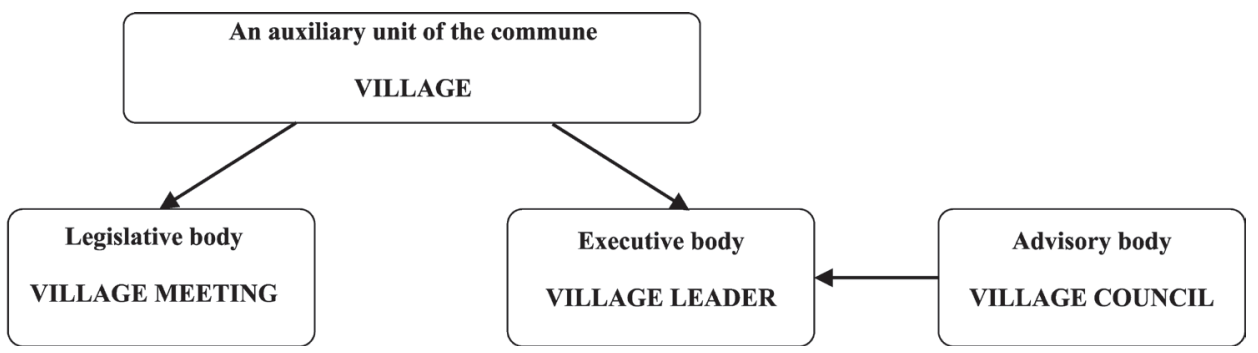

Fig. 1. Village institutional structure

Source: own work based on the Commune Self-government Act.

${ }^{1}$ Urban-rural commune is understood as town and rural areas combined into one administrative unit. 
Assumptions to the Village Fund Act refer to the delivery of commune tasks in auxiliary units of a commune. A village carries out its activities through the village leader (Polish: sołtys) who acts as an executive body for the auxiliary unit of the commune and is assisted by the village council in its advisory capacity. The village meeting is a legislative body composed of all residents of a village (Fig. 1). The Village Fund is separated from the commune's budget by the legislative and overseeing body of a commune and then executed by the executive body of the commune. The size of the fund left at the disposal of a village is calculated pursuant to a unified methodology (1):

$$
\mathrm{F}=\left(2+\frac{\mathrm{L}_{\mathrm{m}}}{100} \mathrm{~K}_{\mathrm{b}}\right)
$$

where:

$\mathrm{F}$ - resources allocated to a village which may not exceed ten times the $\mathrm{K}_{\mathrm{b}}$;

$\mathrm{L}_{\mathrm{m}}$ - number of residents in a village as of 30th June of the year preceding the fiscal year;

$\mathrm{K}_{\mathrm{b}}$ - base amount expressed as a quotient of the current expenditure of a commune - referred to in regulations on public finance - incurred in the year two years prior to the fiscal year and the number of residents of a commune as of $31^{\text {st }}$ December of two years prior to the fiscal year, specified by Statistics Poland (Polish: Główny Urząd Statystyczny).

Pursuant to the provisions of the Village Fund Act, the above-presented solution helps a commune to get some of its costs reimbursed depending on the base amount calculated for a commune in relation to the average base amount for the country. The following three reimbursement thresholds have been defined:

- $40 \%$ in communes where the base amount is lower than the national average;

- $30 \%$ when the base amount in a commune ranges between 100 and $120 \%$ of the national average;

- $20 \%$ when the base amount is higher than $120 \%$ of the average national base amount.

The Village Fund may be used to support the execution of the Spatial Planning and Land Development Act with regard to the drafting of local development plans, studies of the conditions and directions of spatial development, as well as to cover the costs of input data (BPP Katowice, 1983; Feltynowski, 2018a). Sources used to finance the tasks in the area of spatial planning can be traced in documents connected with drafting and executing a commune budget. Budget classification and its organisation in titles and chapters enable the identification of goals to which resources from the portion of the commune budget earmarked for the Village Fund are allocated. 


\section{METHODS AND MATERIALS}

The materials used in the paper come from the data of Statistics Poland concerning the amounts earmarked and disbursed within the Village Fund. Data from the Statistics Poland Local Data Bank cover the period 2014-2016; data availability is limited due to the scope of data collected in individual years and delays in publishing statistics. Information about the resources from the Village Fund is divided into titles and chapters, which was a crucial element of the statistical data, and it provided the grounds for this research (Fig. 2).

For the description of the directions of budget expenditure, it is necessary to examine Title 710 because it covers different kinds of services and includes Sub-chapter 71004, which addresses land-use plans. In accordance with the the binding resolutions of the Court of the Regional Chamber of Audit (Polish: Regionalna Izba Obrachunkowa), this sub-chapter also covers activities undertaken with regard to drafting a study of the conditions and directions of spatial development. For the purpose of this paper, I considered land surveys connected with the merging and splitting of registered plots of land classified in Sub-chapters 71013 and 71014 .

The investigated input data included all rural and urban-rural communes in Poland. First, I assessed the use of the Village Fund in communes, and then I focused on the allocation of resources to specific budget classification titles. As a result, I obtained a set of communes which, between 2014 and 2016, subsidised spatial planning tasks from the Village Fund.

Based on the data received from Statistics Poland, I searched the websites of the Public Information Bulletin (Polish: Biuletyn Informacji PublicznejBIP) to learn about the tasks delivered within the framework of the Village Fund and to identify villages which had decided to allocate financial resources to goals connected with spatial planning. Those queries allowed me to classify tasks and put them in order based on available public information. The latter originated from budget resolutions of communes and reports of commune heads on budget execution. An important aspect of the research involved developing criteria for the division of tasks delivered within the framework of the Village Fund. As a result, I obtained 6 groups of tasks relating to drafting a land-use plan (C1), amending or updating a land-use plan (C2), developing or amending the study of the conditions and directions of spatial development (C3), purchasing the input data necessary for spatial planning (C4), carrying out land surveys (C5), and other tasks intended to improve the quality of an area (C6).

The information obtained from the searches provided the basis for the spatial analysis of the engagement of local communities in the spatial planning process at the commune level. To assess the spatial autocorrelation of those results, 
I used the Global Moran's statistic. This measure helped me in establishing whether the distribution of these territorial units was random or whether there was any spatial autocorrelation (Dube and Legros, 2014). The measure was calculated using the ArcMap software and was based on the Euclidean distance between objects.

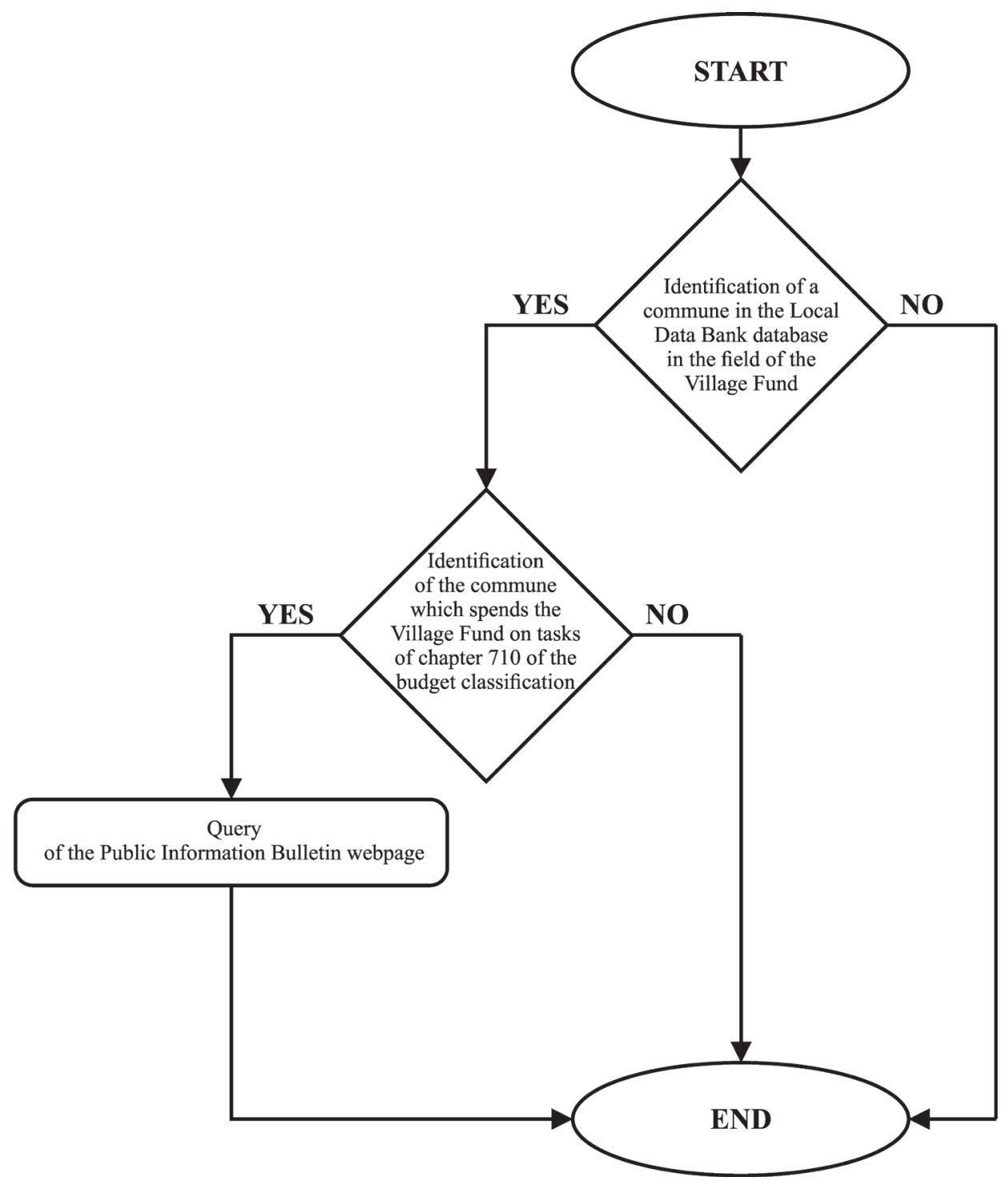

Fig. 2. The procedure adopted in the research on the Village Fund

Source: own work. 


\section{RESULTS}

In accordance with the research procedure, the first stage focused on verifying which rural and urban-rural communes had decided to establish a Village Fund from resources of the commune budget between 2014 and 2016. An analysis of the statistical data led to a conclusion that the establishing of Village Funds in rural and urban-rural communes is a continuous process which attracts an increasingly larger group of recipients.

Table 1. Village Fund in rural and urban-rural communes

\begin{tabular}{|l|c|c|c|c|c|c|}
\hline \multirow{2}{*}{ Commune type } & \multicolumn{3}{|c|}{$\begin{array}{c}\text { Number of communes } \\
\text { with Village Fund }\end{array}$} & \multicolumn{3}{c|}{$\begin{array}{c}\text { Percent of communes } \\
\text { with Village Fund }\end{array}$} \\
\cline { 2 - 8 } & 2014 & 2015 & 2016 & 2014 & 2015 & 2016 \\
\hline Rural & 753 & 916 & 984 & 48.08 & 58.61 & 63.12 \\
\hline Urban-rural & 412 & 449 & 472 & 67.76 & 73.49 & 76.62 \\
\hline Total & 1,165 & 1,365 & 1,456 & 53.59 & 62.79 & 66.95 \\
\hline
\end{tabular}

Source: own work based on Local Data Bank.

The use of Village Funds in communes which have auxiliary units such as a village changed the share of rural communes that pursued those activities over the three examined years by over 15 percentage points. In urban-rural communes, the index amounted to 8.84 percentage points. Considering all the units covered by the analysis, I need to highlight that at the end of 2016, the change reached 13.36 percentage points (Table 1 ).

The first step in the procedure acted as a facilitator for the next stage, which involved identifying communes that had earmarked resources for tasks connected with spatial planning in those communes. In the period covered by the research, only 15 communes had decided to spend resources from the Village Fund on activities that fit within the sub-chapters of budget classification considered in this paper. As with the implementation of the Village Fund, the number of communes allocating resources for their own tasks in spatial planning activities increases every year. The collected analytical data enabled me to conclude that transfers of resources from the Village Fund to tasks relating to spatial planning were experimental occurrences covering, at best, two years of the period included in the study.

In accordance with the Global Moran's used as a measure, I could confirm that the spatial distribution of communes which allocated resources to spatial planning-related tasks was random. Additionally, the distribution was not uniform across voivodeships because, in the Zachodniopomorskie, Lubuskie, Lower Silesia, and Podkarpackie Voivodeships, not a single Village Fund was detected 
that spent resources on tasks pertaining to spatial planning. In the Opolskie and Mazowieckie Voivodeships, there were, respectively, two and three communes whose Village Funds included tasks in spatial planning (Fig. 3).

According to our research, activities involving tasks connected with spatial planning were carried out in 24 villages. An examination of their budgets made it possible to match tasks attributed to Village Funds with selected groups of outlays connected with spatial planning. The village which I investigated carried out 27 activities in total that were linked to funding tasks coupled with spatial planning. Based on the classification groups, over $1 / 4$ of the tasks concerned drafting new land-use plans. The task was connected with activities involved in updating or amending existing local plans, identified in almost $15 \%$ of cases. The situation was similar for tasks connected with drafting or amending the study of conditions as well as land surveys undertaken to put the land in order. In both cases, the identified tasks comprised less than $15 \%$ of the analysed set. The purchase of input data necessary to accomplish tasks relating to spatial planning in communes applied to less than $7.5 \%$ of the investigated tasks. Other work connected with introducing spatial order in a commune accounted for $22 \%$ of cases.

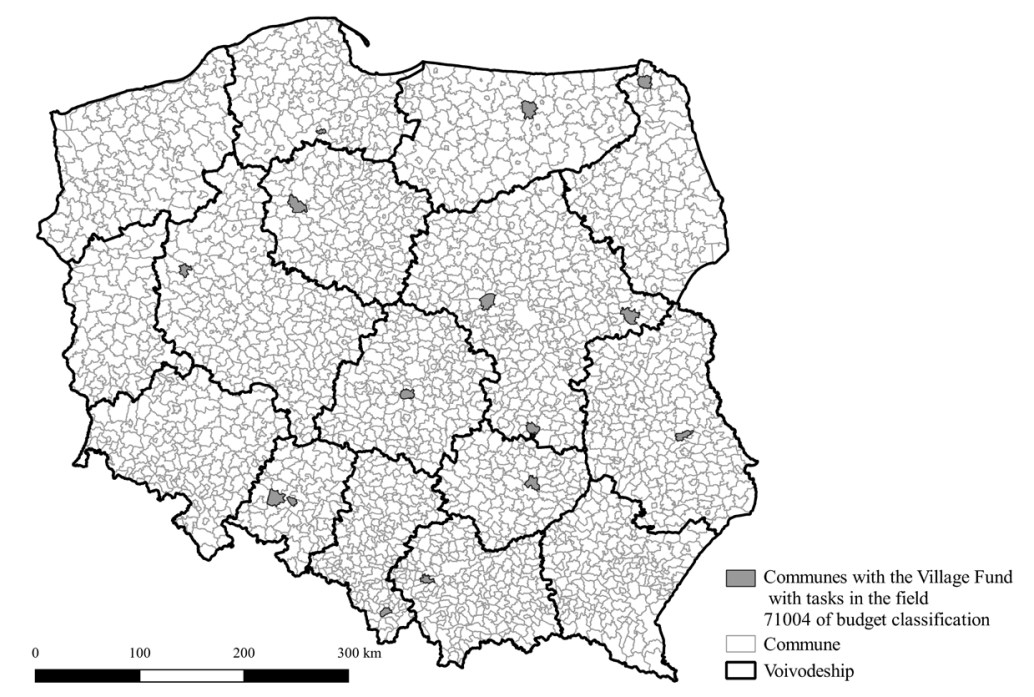

Fig. 3. Communes with Village Fund with spatial planning tasks budgeting in the years 2014-2016 Source: own work based on budget data and spatial data from Head Office of Geodesy and Cartography. 
The average outlays on tasks relating to spatial planning in the examined group reached almost PLN 4,689. The projects accomplished in a village ranged from PLN 500 to 16,000 . The activities that they carried out consumed slightly more than $35 \%$ of the resources at the disposal of the village which decided to spend them on efforts connected with spatial planning (Table 2).

Table 2. Tasks related to spatial planning implemented as part of Village Fund

\begin{tabular}{|l|c|c|c|c|}
\hline \multirow{2}{*}{ Task } & \multicolumn{2}{|c|}{ Value of accomplished projects } & \multirow{2}{*}{$\begin{array}{c}\text { Share of Village Funds } \\
\text { implementing individual tasks }\end{array}$} \\
\cline { 2 - 4 } & Average & MIN & MAX & 55.8 \\
\hline C1 & 6959.29 & 1300 & 16,000 & 55.2 \\
\hline C2 & 8628.11 & 5000 & $11,572.7$ & 22.2 \\
\hline C3 & 2708.91 & 910 & 5108.98 & 13.2 \\
\hline C4 & 1740 & 500 & 2980 & 35.2 \\
\hline C5 & 2952.5 & 1476 & 4182 & 17.1 \\
\hline C6 & 2873.83 & 1243 & 6500 & 35.3 \\
\hline Total & 4688.74 & 500 & 16,000 & \\
\hline
\end{tabular}

Source: own work.

The analysis of the financial outlays relating to spatial planning has helped me to highlight projects which demanded large expenditures from the Village Fund. As expected, the biggest average amount allocated to the delivery of tasks was found for expenditure class 2 (C2), i.e. amending or updating land-use plans. The average amount paid out for this purpose amounted to PLN 8,628.11. Big average outlays were also made on drafting new land-use plans $(\mathrm{C} 1)$, where the average amount reached PLN 6,959.29.

Of the above-mentioned expenditure lines, the smallest sums were paid for acquiring input data for spatial planning $(\mathrm{C} 4)$. The average amount, in this case, was PLN 1,740. Relatively small sums were allocated to tasks related to the drafting or amending of a study of conditions (C3), PLN 2,708.91 on average. The average outlays on land surveys (C5) and other tasks intended to improve the quality of an area (C6) did not exceed PLN 3,000.

Looking at these results in terms of the share of resources allocated to different objectives and spent on activities relating to spatial planning from the Village Fund, the highest percentage of resources was earmarked for tasks from group C1 (55.8\% of all the resources from the Village Fund). A similar share was reported for activities from group C2 (55.2\%). On the other extreme, there were tasks connected with the purchase of input data $(\mathrm{C} 4)$ whose results for financial outlays overlapped - as with groups $\mathrm{C} 1$ and $\mathrm{C} 2$. When it comes to tasks from group C4, 
expenditure from the Village Fund amounted to only 13.2\%. Investment projects intended to improve the quality of areas in communes (C6) required $17.1 \%$ of the Village Fund. The share of activities from group C3 slightly exceeded 22.2\% while land surveys (C5) required about $35 \%$ of resources.

\section{DISCUSSION AND CONCLUSION}

The results of the research have led to the conclusion that only a few villages in Poland decided to earmark financial resources from the Village Fund for tasks connected with spatial planning. Admittedly, such decisions were marginal compared to other tasks delivered from the resources of the fund in question. Much bigger amounts and more projects were identified for activities such as the modernisation of public premises, improved access to information and better communication between local authorities and residents, higher quality of the technical infrastructure (including roads and lightning), the promotion of a village, providing meeting places and ensuring social integration, organising local cultural and educational events, and increasing the share of green areas in villages (Feltynowski and Rzeńca, 2019).

The actions undertaken in villages did not allow for full financing of the tasks connected with spatial planning. However, one needs to bear in mind that they lay the foundations for financial engineering based on the resources left at the disposal of a village and local communities. This approach may also provide the basis for initiatives paid from off-budget resources (Filipiak and Dylewski, 2015; Kamiński, 2012). This study was also intended to assess the openness of the rural population to the co-financing of projects linked to spatial planning from the Village Fund. In this context, it needs to be stressed that local self-governments whose auxiliary units carry out investment projects financed from the Village Fund are obliged to inform local communities what tasks may be paid from these resources.

The obtained data was not very optimistic, although it needs to be acknowledged that the 24 villages which were identified should be seen as examples of best practices when it comes to the openness of both the local community as well as the local authorities which promote spending from the Village Fund on tasks in the area of spatial planning. Unfortunately, the resources allocated to this goal are very limited, which, in the light of the estimated market price for a local development plan of one hectare in size, means they are not sufficient to pay for any local plan for a big area (Feltynowski, 2018a).

The results of the study also demonstrated that some of the groups distinguished in the research study generated big average amounts, which absorbed 
more than half of the Village Fund. Other groups, despite value indicators higher than minimal, did not absorb significant resources from the fund. Nonetheless, regardless of the group of tasks connected to spatial planning, one must point out that only 24 out of more than 40,000 rural administrative units financed these types of tasks. It is hard to find a single voivodeship that uses the Village Fund for spatial planning activities to a significant degree.

The use of Village Fund in rural and urban-rural communes should be seen as a wish to build a civil society in which the residents decide about the allocation of financial resources made available to them by local authorities. It also develops relations between local authorities and the community. We need to bear in mind that these activities should be promoted further, which calls for awareness building among council members in communes as they are responsible for establishing the Village Fund out of a commune's budget.

\section{REFERENCES}

Biuro Planowania Przestrzennego Katowice (BPP Katowice) (1983). Materiały wejściowe. Katowice: BPP Katowice.

BRZEZIŃSKI, C. (2015), Polityka przestrzenna w Polsce. Instytucjonalne uwarunkowania na poziomie lokalnym i jej skutki finansowe. Łódź: Wydawnictwo Uniwersytetu Łódzkiego.

BRZEZIŃSKI, C. (2016), 'Threats of sustainable development resulting from legal requirements of spatial planning in Poland', Economic and Environmental Studies, 16, 2 (38), pp. 319-330.

CHRISIDU-BUDNIK, A. and KORCZAK, J. (2018), 'The Role of Trust in Spatial Planning Processes: The Case of Poland', [in:] KOŻUCH, B., MAGALA, S. and PALISZKIEWICZ, J. (eds), Managing Public Trust. Cham: Palgrave Macmillan, pp. 255-272.

Commune Self-government Act of 8 March 1990. J. of L. (1990), 16 (95), as amended.

DUBE, J. and LEGROS, D. (2014), Spatial Econometrics Using Microdata. New York: John Wiley $\&$ Sons, Inc.

FELTYNOWSKI, M. (2018a), Planowanie przestrzenne gmin wiejskich. Zastosowanie koncepcji polityki opartej na dowodach. Łódź: Wydawnictwo Uniwersytetu Łódzkiego.

FELTYNOWSKI, M. (2018b), 'Level of spatial planning culture of rural gminas in the central region of Poland', Infrastruktura i Ekologia Terenów Wiejskich, II (1), pp. 293-304.

FELTYNOWSKI, M. and RZEŃCA, A. (2019), 'Solecki fund as instrument in the hands of rural development policy makers: the case of rural communes of the Lodz Metropolitan Area in Poland', [in:] KRAKOWIAK-BAL, A. and VEVERKOVA, M. (eds.), Infrastructure and Environment, Springer, Cham, pp. 263-271.

FILIPIAK, B.Z. and DYLEWSKI, M. (2015), 'Działalność inwestycyjna jednostek samorządu terytorialnego w latach 2008-2013', Zeszyty Naukowe Uniwersytetu Szczecińskiego, 854. Finanse, Rynki Finansowe, Ubezpieczenia, 73, pp. 867-877.

JAŁOWIECKI, B. (1986), 'Próba oceny badań nad Polską lokalną. Wstępne wyniki badań', Seria: Polska lokalna $i$ samorzad terytorialny $w$ warunkach reformy i rekonstrukcji gospodarki przestrzennej, 2, pp. 57-78.

KAMIŃSKI, A. (2012), Finansowanie dlużne w jednostkach samorządu terytorialnego. Warsaw: Wolters Kluwer Polska. 
KOLIPIŃSKI, B. (2015), 'Przywróćmy wysoką kulturę planowania przestrzennego', [in:] KALINOWSKA, A. (ed.). Miasto idealne - miasto zrównoważone. Planowanie przestrzenne terenów zurbanizowanych i jego wpływ na ograniczenie skutków zmian klimatu. Warsaw: Uniwersyteckie Centrum Badań nad Środowiskiem Przyrodniczym i Zrównoważonym Rozwojem, pp. 169-175.

MISZTAL, B. (1986), 'Przemiany restrukturyzacyjne społeczności lokalnych. Wstępne wyniki badań, Seria: Polska lokalna i samorzad terytorialny w warunkach reformy i rekonstrukcji gospodarki przestrzennej, 2, pp. 79-92.

NOWAK, M.J. (2012), Decyzje o warunkach zabudowy i zagospodarowania terenu w gospodarowaniu i zarzadzaniu przestrzenia. Warsaw: CeDeWu.

Spatial Planning and Land Development Act of 27 March 2003. J. of L. (2003), 80 (717) as amended.

STAROSTA, P. (1995), Poza metropoliq. Wiejskie i małomiasteczkowe zbiorowości lokalne a wzory porząku makrospołecznego. Łódź: Wydawnictwo Uniwersytetu Łódzkiego.

Village Fund Act of 20 February 2009. J. of L. (2009), 52 (420) as amended.

Village Fund Act of 21 February 2014. J. of L. (2014), 301, as amended. 